\title{
Phenotypic Diversity within Ipomoea Mauritiana Jacq. (Ksheeravidari) Germplasm Collections
}

\author{
Lakshmi Mohan N. ${ }^{1, *}$, SadheeshnaKumari S. ${ }^{2}$, Geetha S. Pillai ${ }^{2}$ \\ ${ }^{1}$ Department of Biotechnology, School of Life Sciences, Kannur University, Kerala, India \\ ${ }^{2}$ Crop Improvement \& Biotechnology Division, Centre for Medicinal Plants Research (CMPR), India
}

Received October 20, 2019; Revised November 26, 2019; Accepted December 4, 2019

Copyright $\mathrm{C} 2020$ by authors, all rights reserved. Authors agree that this article remains permanently open access under the terms of the Creative Commons Attribution License 4.0 International License

\begin{abstract}
The morphological parameters have been widely used in the evaluation of various crops. Quantitative and qualitative characters of 18 phenotypes of Ipomoea mauritiana Jacq, collected from various locations of Kerala were studied and data were recorded. Various qualitative data collected were grouped using PAUP software and dendrogram was constructed using UPMGA. The morphological characters like vine color, plant type, root formation, root color, root shape were the same and notable variations were seen in leaf lobe number, leaf color, leaf length and breadth, petiole length, petiole color. The morphology of tubers was studied after one year of planting and the data were scored and tabulated. The phenotypic variations provide an easy way to assess the accessions and for further evaluations. The variations were most expressed in the leaf colour, vine color, petiole colour, leaf length, leaf breadth, tuber fresh weight, tuber dry weight, tuber dry recovery percentage, number of roots formed per plant. From dendogram IM- 6 showed much significant morphological variation from others. Furthermore studies have to be done to confirm existence of any genetic variations amongst them by carrying out experiments using molecular techniques.
\end{abstract}

Keywords Ipomoea mauritiana, Morphological Characters

\section{Introduction}

Ipomoea mauritiana Jacq is an important medicinal plant that belongs to the Convolvulaceae family. The species is distributed throughout India in deciduous and evergreen forests and coastal tracts. It is a much branched glabrous twining perennial shrub with large tuberous roots, which are the source of Ayurvedic raw drug Ksheeravidari, a rejuvenating drug [15]. It is used in more than 50
Ayurvedic formulations. The roots are sweet, have cooling properties, and are used to increase appetite, as a galactagogue, in rejuvenative medicine, as a stimulant, carminative and tonic. The annual requirement for this raw material in the state is nearly 200 tones [14]. Overexploitation of the species for use as raw material in pharmaceutical industry exerts great pressure on the natural resources and hence results either in their non-availability in required quantities or even disappearance from the wild. Large-scale cultivation is the only practical solution for making the raw drug available to the industry. Cultivation of this species becomes un-economical due to poor yield and lack of improved lines and hence organized cultivation of I. mauritiana is now taken up in the state.

Plant genetic resources are the most valuable and essential raw material in meeting the current and future needs of crop improvement programs. Morphological characterization of genetic resources is very essential for the detection of desirable traits, identification of duplicate accessions so as to save the storage space, structuring of population for conservation and simplifying selection by plant breeders [12, 8]. Diversity can be accessed by measuring the variation in the phenotypic traits. Phenotypic descriptors are useful for evaluating and identifying genetic relationships among accessions. Morphological diversity is evaluated through assessment of variation in phenotypic characters including both above and below ground traits [11]. Morphological characterization is the primary step that needs to be carried out before biochemical and molecular studies [2].

In the case of $I$. mauritiana there is no previous information on the genetic variability available in the germplasm. Improvement work in this species may be limited by the lack of knowledge of available genetic diversity and therefore, comprehensive information concerning locally available germplasm is of vital importance for development of improved lines. The 
genotypic variability using RAPD markers, which revealed only narrow variability, was studied by Lakshmi et al [7].

The aim of this research, therefore, was to morphologically characterize 18 genotypes of $I$. mauritiana, collected from different locations within Kerala, for utilization in the breeding efforts aimed at high yield and storage root quality.

\section{Materials and Methods}

\subsection{Study Area}

The study site was Centre for Medicinal Plants Research, AryaVaidyaSala, Kottakkal, Malappuram, Kerala, India (longitude: $75.9918^{\circ} \mathrm{E}$ and latitude: $10.9990^{\circ} \mathrm{N}$ and elevation $25 \mathrm{M}$ ). The soil is laterite in texture. This region has tropical climatic conditions which receives both South West and North East monsoon and the annual rainfall ranges from 2900-3000 $\mathrm{mm}$. The average annual temperature ranges from $25^{\circ} \mathrm{C}-38^{\circ} \mathrm{C}$.

A collection of 18 Ipomoea mauritiana (IM) genotypes collected from different agro-climatic zones in Kerala were utilized for this study. The collection strategy consisted of visiting the different agro-climatic regions at random and collected one or more tubers or vines from each genotype (Table 1). Thus, a total of 18 genotypes were assembled and multiplied through vine cuttings in the nursery to raise sufficient replicates for evaluation.

The experiment was conducted for the period from 2014 to 2017 and these genotypes were planted in the field under ex situ conditions in CMPR campus field. These genotypes were planted in grow bags $(35 \mathrm{cmx} 20 \mathrm{~cm})$ and kept under the field conditions. Vine cuttings of $7 \mathrm{~cm}$ are planted $2 \mathrm{~cm}$ deep and the grow bags were kept with a spacing of $60 \mathrm{~cm}$ between plants at the onset of the planting season in the month of June. Prior to keeping the plants in the field, they were maintained in the nursery, where initial observations were taken. In the main field the genotypes were arranged in Randomized Block Design with three replications. Each genotype was represented with three plants.

As no recommended standard cultivation practices are available for IM, the cultural operation developed at the author's division (unpublished) was followed uniformly for all experimental plots. As no crop descriptors are available for the crop, the characters to be scored for morphological characterization as shown in Table 2 were selected using the descriptors for Ipomoea batatas developed by CIP/AVRDC/IBPGR [3] with exception of some traits.

Table 1. Ipomoea mauritiana collections, with their respective area of collection in Kerala

\begin{tabular}{|c|c|c|c|}
\hline Collection number & Collection site & Collection number & Collection site \\
\hline IM-1 & Herb Garden-Malappuram & IM-10 & Valanchery, Malappuram \\
\hline IM-2 & Kottakkal, Malappuram & IM-11 & Edappal, Malappuram \\
\hline IM-3 & KAU-I, Thrissur & IM-12 & Valiyakunnu, Malappuram \\
\hline IM-4 & Kottappuram, Malappuram & IM-13 & Attappadi, Palakkad \\
\hline IM-5 & Kanjirapuzha, Palakkad & IM-14 & Kottakkal, Malappuram \\
\hline IM-6 & Nileswaram, Kasaragod & IM-15 & Eranakulam \\
\hline IM-7 & Cheemeny, Kasaragod & IM-16 & Peechi, Thrissur \\
\hline IM-8 & Valiyakunnu, Malappuram & IM-17 & Padinjattumuri, Malappuram \\
\hline IM-9 & Kanjirapuzha, Palakkad & IM-18 & Muthanga, Wayanad \\
\hline
\end{tabular}


Phenotypic Diversity within Ipomoea Mauritiana Jacq. (Ksheeravidari) Germplasm Collections

Table 2. Descriptors used to assess the agromorphological characters in Ipomoea mauritiana genotypes.

\begin{tabular}{|c|c|c|}
\hline Plant part & Morphological traits & \\
\hline \multicolumn{3}{|l|}{ Vine } \\
\hline & Twining & 1. Twining, 2. Slightly twining, 3. Moderately twining, 4 . Twining, 5. Very twining \\
\hline & Plant type & $\begin{array}{l}\text { 1. Erect }(<75 \mathrm{~cm}), 2 . \text { Semi-erect }(75-150 \mathrm{~cm}), 3 . \text { Spreading }(151-250 \mathrm{~cm}), 4 \text {. Extremely spreading } \\
(>250 \mathrm{~cm})\end{array}$ \\
\hline & Vine pigmentation & \\
\hline & Predominant vine colour & $\begin{array}{l}\text { 1. Green, 2. Green with few purple spots, } 3 \text {. Green with many purple spots, } 4 \text {. Green with many } \\
\text { dark purple spots, } 5 \text {. Mostly purple, } 6 \text {. Mostly dark purple, } 7 \text {. Totally purple, } 8 \text {. Totally dark } \\
\text { purple }\end{array}$ \\
\hline & Secondary vine colour & $\begin{array}{l}\text { 1. Absent, 2. Green base, 3. Green tip, 4. Green nodes, 5. Purple base, 6. Purple nodes, 7. Others } \\
\text { (specify) }\end{array}$ \\
\hline & Vine Tip Pubescence & 1. Absent, 2. Sparse, 3. Moderate, 4. Heavy \\
\hline & Vine Internode & \\
\hline & Vine Internode Length & $\begin{array}{l}\text { 1. Very short }(<3 \mathrm{~cm}), 2 \text {. Short }(4-\mathrm{mm}), 3 \text {. Intermediate }(7-9 \mathrm{~mm}), 4 \text {. Long }(10-12 \mathrm{~mm}) \text {, Very } \\
\text { long }(>12 \mathrm{~mm})\end{array}$ \\
\hline & Vine Internode Diameter & $\begin{array}{l}\text { 1. Very thin }(<4 \mathrm{~mm}), 2 \text {. Thin }(3-5 \mathrm{~cm}), 3 \text {. Intermediate }(6-9 \mathrm{~cm}), 4 \text {. Thick }(10-12 \mathrm{~cm}) \text {, Very thick } \\
(>12 \mathrm{~cm})\end{array}$ \\
\hline \multirow[t]{10}{*}{ Leaf } & Mature leaf shape & \\
\hline & $\begin{array}{l}\text { General Outline of the } \\
\text { Leaf }\end{array}$ & 1. Rounded, 2. Reniform, 3. Cordate, 4. Triangular, 5. Lobed, 6. Almost divided \\
\hline & Leaf Lobe Type & 1. Entire, 2. Teethed, 3. Slight, 4. Moderate, 5. Deep, 6. Very deep \\
\hline & Leaf Lobe Number & 1 (Round apex), 2 (with central tooth), 3. 3-lobed, 4. 5-lobed, 5. 7-lobed \\
\hline & $\begin{array}{l}\text { Shape of Central Leaf } \\
\text { Lobe }\end{array}$ & $\begin{array}{l}\text { 1. Absent, 2. Toothed, 3. Triangular, 3. Semicircular, 4. Semielliptic, 5. Elliptic, 6. Lanceolate, } 7 . \\
\text { Oblanceolate, 8. Linear (Broad / Narrow) }\end{array}$ \\
\hline & Mature Leaf size & 1. Small, 2. Medium, 3. Large, 4. Very large \\
\hline & Mature Leaf Colour & $\begin{array}{l}\text { 1. Yellow green, 2. Green, 3. Green with purple edge, } 4 \text {. Greyish green, 5. Green with purple } \\
\text { veins on upper surface, } 6 \text { Slightly purple, } 7 \text {. Mostly Purple }\end{array}$ \\
\hline & $\begin{array}{l}\text { Abaxial Leaf Vein } \\
\text { Pigmentation }\end{array}$ & $\begin{array}{l}\text { 1. Yellow, } 2 \text {. Green, } 3 \text {. Purple spot in the base of the main rib, } 4 \text {. Purple spots in several veins, } 5 \text {. } \\
\text { All veins mostly or totally purple, } 6 \text {. Lower surface and veins totally purple }\end{array}$ \\
\hline & Petiole Pigmentation & $\begin{array}{l}\text { 1. Green, 2. Green with purple near stem, } 3 \text {. Green with purple near leaf, } 4 \text {. Green with purple at } \\
\text { both ends, } 5 \text {. Green with purple spots throughout the petiole, } 6 \text { Green with purple stripes, } 7 \text { Purple } \\
\text { with green ear leaf, } 8 \text {. Totally or mostly purple }\end{array}$ \\
\hline & Petiole Length & 1. Very short, 2, Short, 3. Intermediate, 4. Long, 5. Very long \\
\hline \multirow[t]{16}{*}{$\begin{array}{l}\text { Storage } \\
\text { root }\end{array}$} & $\begin{array}{ll}\text { Storage } & \text { Root } \\
\text { Arrangement } & \end{array}$ & 1. Closed cluster, 2. Open cluster, 3. Dispersed, 4. Very dispersed \\
\hline & Storage Root Shape & $\begin{array}{l}\text { 1. Round, 2. Round elliptic, 3. Elliptic, 4. Ovate, 5. Obvate, 6. Oblong, 7. Long oblong, 8. Long } \\
\text { elliptic, 9. Long irregular or curved }\end{array}$ \\
\hline & Storage Root Size & 1. Uniform, 2. Slightly variable, 3. Moderately variable \\
\hline & Storage Root Defects & 1. Absent, 2. Alligator-like skin, 3. Veins, 4. Horizontal constrictions, 5. Longitudinal grooves \\
\hline & $\begin{array}{l}\text { Predominant Root Skin } \\
\text { Colour }\end{array}$ & 1. White, 2. Cream, 3. Yellow, 4. Orange \\
\hline & $\begin{array}{l}\text { Intensity of predominant } \\
\text { root skin colour }\end{array}$ & 1. Pale, 2. Intermediate, 3. Dark \\
\hline & $\begin{array}{l}\text { Predominant Root Flesh } \\
\text { Colour }\end{array}$ & 1. White, 2. Cream, 3. Dark cream, 4. Pale Yellow \\
\hline & Secondary Flesh Colour & 1. Absent, 2. White, 3. Cream, 4. Yellow, 5. Orange \\
\hline & $\begin{array}{l}\text { Distribution of secondary } \\
\text { flesh colour }\end{array}$ & $\begin{array}{l}\text { 1. Absent, 2. Narrow ring in cortex, 3. Broad ring in cortex, 4. Scattered spots in flesh, 5. Ring } \\
\text { and other areas in flesh, } 6 \text {. Covering all flesh }\end{array}$ \\
\hline & $\begin{array}{l}\text { Number of Roots Per } \\
\text { Plant }\end{array}$ & Average of ten plants \\
\hline & Root Cracking & 1. Absent, 2. Few cracks, 3. Medium number of cracks, 4. Many cracks \\
\hline & Root Latex Production & 1. Little, 2. Some, 3. Abundant \\
\hline & Root Cortex Thickness & $\begin{array}{l}\text { 1. Very thin }(<1 \mathrm{~mm}), 2 \text {. Thin }(1-2 \mathrm{~mm}), 3 \text {. Intermediate }(2-3 \mathrm{~mm}), 4 \text {. Thick }(3-4 \mathrm{~mm}) 5 \text {. Very } \\
\text { Thick }>4 \mathrm{~mm})\end{array}$ \\
\hline & $\begin{array}{l}\text { Fresh Weight of Storage } \\
\text { Root }\end{array}$ & Average weight of roots from 3 plants \\
\hline & $\begin{array}{l}\text { Dry Weight of Storage } \\
\text { Roots }\end{array}$ & Average dry weight of roots from 3 plants \\
\hline & Percent Dry Recovery & Average of dry recovery percent \\
\hline
\end{tabular}


Out of the total 39 characters selected, 27 were qualitative and 12 were quantitative. For morphological characterization various parts were examined and data were recorded. The plant characters were recorded at about one month from planting. The characters related to length or sizes were scored as the average value of measurements made on 3 plants of each collection. Vine and leaf characters were scored as the average expression of characters observed in a section of the main stem, located in the middle portion of several main stems. The morphology of tubers was studied after one year of planting. Various qualitative data collected were grouped using PAUP software and dendrogram was constructed using UPMGA. Quantitative data were noted and tabulated.

\section{Results and Discussion}

The results of the study indicated that the variation within 18 IM collections could be generally categorized under highly significant, significant and non-significant (Figure 1). The highly significant and significant variations in morphological traits are given in Table 3. Parameters such as twining habit, extremely spreading plant type pattern and lobed leaf shape were shared by all the collections. Vine colour showed wide range of variation with seven phenotypic expressions such as green $(\mathrm{G})$, totally purple (TP), mostly purple (MP), totally dark purple (TDP), mostly dark purple (MDP), green with many dark purple spots (GDPS) and Green with many purple spots (GMPS). Most prominent vine colour was GPS (33.33\%) followed by MP (22.22\%). MDP, G or TP were expressed by $11.11 \%$ each of the collections and $5.55 \%$ each of the collections expressed phenotypes such as TDP and GDPS.
The leaf lobe type was mostly deep or very deep except for IM-6 in which it was moderately lobed. Moderate vine tip pubescence was expressed by $66.66 \%$, while $33.33 \%$ expressed sparse type.

A good number of the collections under study had green leaf colour $(55.55 \%)$, followed by one with green leaves with purple veins on upper surface $(27.78 \%)$ and those having green leaves with purple edge $(11.11 \%)$. Two collections (IM-2 and IM-4) exhibited both leaf colour phenotypes (green leaves with purple veins on upper surface and green leaves with purple edge). The most frequent petiole color expressed (55.55\%) was totally or mostly purple (TMP) followed by $22.22 \%$ collections having green with purple near leaf (GPNL), and then $11.11 \%$ having green with purple spots throughout petiole (GPSTP). Two collections (IM-3 and IM-17), showed both characters such as green with purple spots throughout petiole and green with purple near leaf.

Eleven out of eighteen collections (61.11\%) shared similar root shape of long irregular or curved with dark brownish color. Three collections (IM-1, IM-5 and IM-13) were with long elliptic storage roots, while IM-2 was with obovate roots. Long oblong storage roots were observed in IM-6 and IM-14. The root form showed less variation with two phenotypes (open and closed). Open type root form was observed in $72.22 \%$ of the collections and in $22.22 \%$ collections it was closed cluster type, whereas in collections IM-3 and IM-17 only one tuber could be obtained. The commonly found root surface defect was veins and alligator like skin. Five collections (IM-3, IM-4, IM-6, IM-8 and IM-11) showed horizontal constrictions also. Root cracking was almost absent in IM-6, IM-15 and IM-17, other expressed few, many or medium root cracking. Significant qualitative data was shown in table 3. 

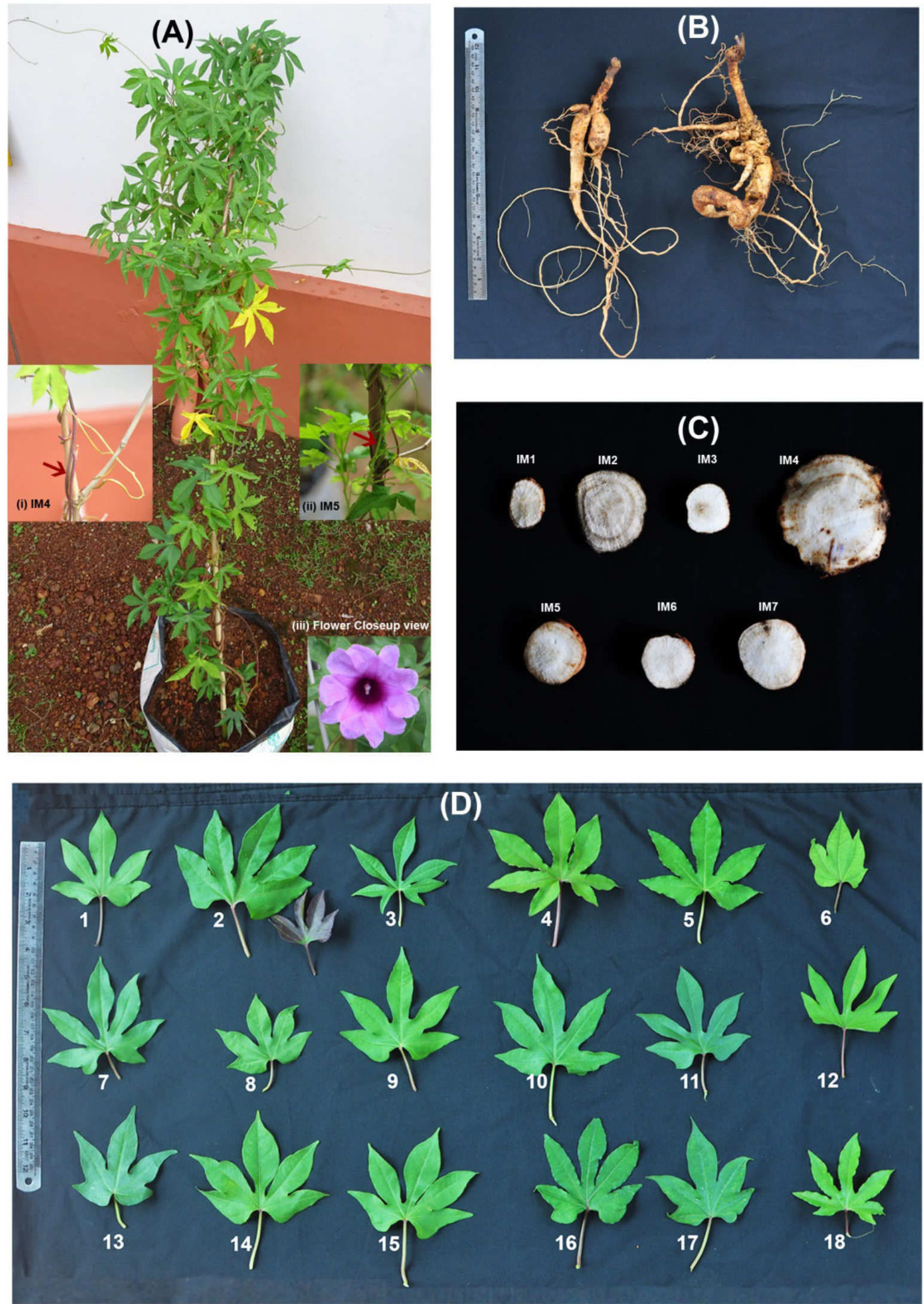

Figure 1. Ipomoea mauritiana (IM): - (A) Habit,- (i) \& (ii) (inset) Closeup of mature stem showing distict colour variation between IM4 \& IM5, (iii) Closeup of IM flower; (B) Tuberous roots of IM1; (C) Variations in cross section of tuberous roots of IM collections (IM1-IM7); (D) Variation in leaf colour, shape, sizes among all the 18 collections 
Table 3. Selected significant qualitative characters of 18 genotypes of IM

\begin{tabular}{|c|c|c|c|c|c|c|c|}
\hline Collections & $\begin{array}{c}\text { Color of } \\
\text { vines }\end{array}$ & Petiole color & Leaf color & Root shape & $\begin{array}{c}\text { Root } \\
\text { formation }\end{array}$ & $\begin{array}{c}\text { Root surface } \\
\text { defects }\end{array}$ & $\begin{array}{c}\text { Root } \\
\text { cracking }\end{array}$ \\
\hline IM1 & MDP & TMP & GWPVUS & LE & Open & V/A & Medium \\
\hline IM2 & MP & TMP & $\begin{array}{c}\text { GWPE/GWP } \\
\text { VUS }\end{array}$ & O & Open & Vany \\
\hline IM3 & MP & GWPSTP & GWPE & LIC & One tuber & V/HC & Many \\
\hline IM4 & TDP & TMP & $\begin{array}{c}\text { GWPE/GWP } \\
\text { VUS }\end{array}$ & LIC & Closed & A & Many \\
\hline IM5 & G & GWPNL & G & LE & Open & V/A & Many \\
\hline IM6 & MDP & TMP & GWPVUS & LO & Open & A/HC & Absent \\
\hline IM7 & GWMDPS & TMP & G & LIC & Open & A/V & Many \\
\hline IM8 & GWMPS & GWPS & G & LIC & Closed & V/HC & Few \\
\hline IM9 & GWMPS & GWPS & G & LIC & Open & V/A & Few \\
\hline IM10 & G & GWPSTP & G & LIC & Open & V & Many \\
\hline IM11 & MP & TMP & G & LIC & Open & V/A & Few \\
\hline IM12 & GWMPS & TMP & GWPVUS & LO & Closed & V & Few \\
\hline IM13 & MP & TMP & G & LIC & Open & V & Many \\
\hline IM14 & GWMPS & GWPNL & G & LE & Open & A & Many \\
\hline IM15 & TP & GWPNLTP & G & LO & Closed & V & Absent \\
\hline IM16 & TP & GWPNL & GWPVUS & LIC & Open & A & Many \\
\hline IM17 & GWMPS & TMP & G & LIC & One tuber & V & Absent \\
\hline IM18 & GWMPS & TMP & GWPVUS & LIC & Open & Medium \\
\hline
\end{tabular}

Color of vine: MDP - Mostly Dark Purple, MP - Mostly Purple, TDP - Totally Dark Purple, G - Green, GWMDPS - Green With Many Dark Purple Spots, GWMPS - Green with Many Purple Spots, TP - Totally Purple, Petiole colour: TMP- Totally or Mostly Purple, GWPSTP - Green with Purple Spots Throughout petiole, GWPNL - Green with purple near leaf, G-Green, Color of leaves: Green With Purple Veins on Upper Surface, GWPE-Green With Purple Edge, G- Green, Root Shape: LE- Long Elliptic, O- Oblong, LIC- Long Irregular or Curved, LO- Long oblong, Root surface defects: V-Veins, A-Alligator like Skin, HC- Horizontal constrictions

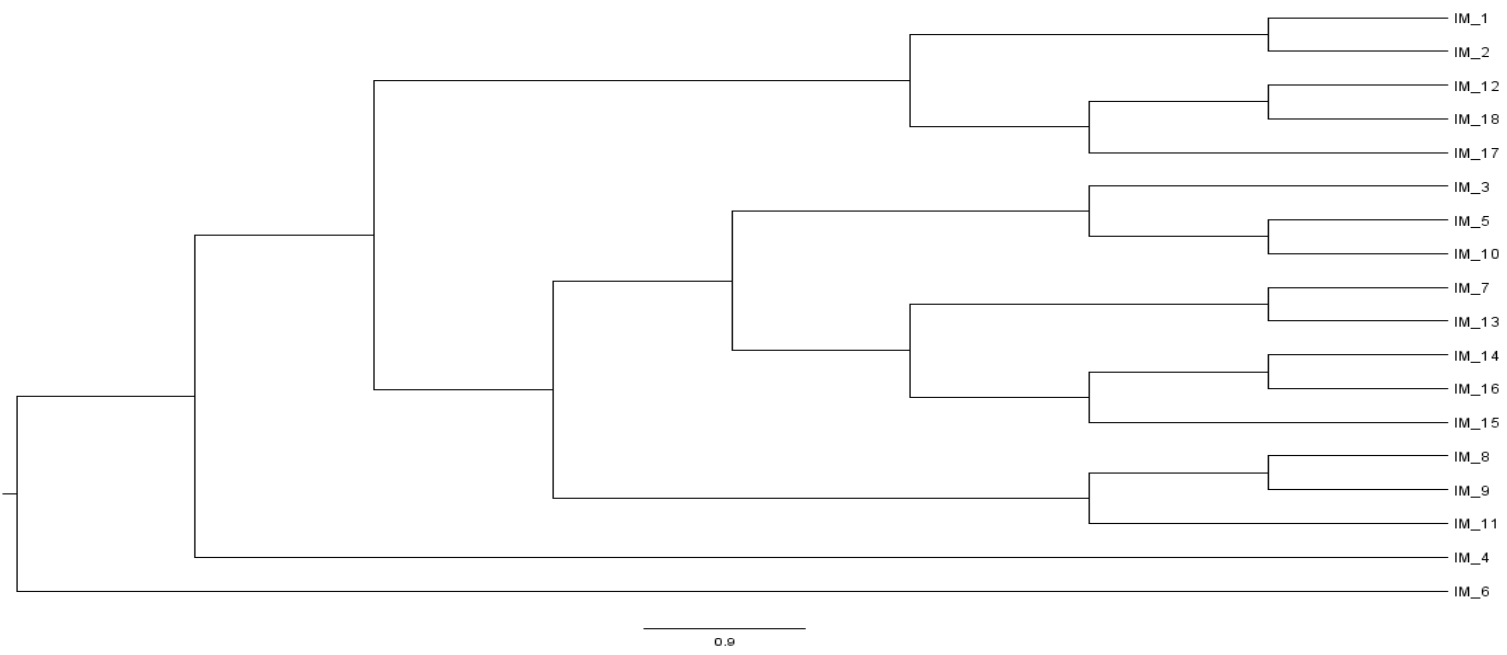

Figure 2. Dendrogram based on the variation in morphology

From dendrogram, the 18 collections were divided into two groups, one with IM- 6 alone and the $2^{\text {nd }}$ with other 17 genotypes of the collections, i.e., IM-6 showed much significant morphological variations. The $2^{\text {nd }}$ group was again clustered into two with IM-4 alone and other 16 collections in the $2^{\text {nd }}$ cluster, showing IM-4 was slightly variant from the others in the same group. The cluster containing 16 collections was sub-divided into two with 5 collections falling in one group and 11 others falling in the $2^{\text {nd }}$ group (Figure 2)

$1^{\text {st }}$ group

IM-1 \& IM-2 shares almost all the morphological characters except i. secondary vine color ii. Root shape iii. Root cracking iv. Mature leaf size and v. primary vine pigmentation.

$2^{\text {nd }}$ group

IM-12 and IM-18 differs in i. Surface defect, root 
formation and root cracking. IM-17 is closely placed in this group, as it only differs in secondary vine pigmentation, petiole pigmentation and root cracking from IM-12 and IM-18.

\section{$3^{\text {rd }}$ group}

IM-5 and IM-10 differ in leaf vein pigmentation, petiole pigmentation, variability in root size and mature leaf size. IM-3 is closely placed to IM-5 and IM-10, as it shares the same secondary vine characters with IM-5 and IM-10, shares same leaf vein pigmentation with IM-5 alone and same immature leaf color with IM-10.

\section{$4^{\text {th }}$ group}

IM-7 and IM-13 differ in primary vine pigmentation, root shape, intensity of root skin color, root formation and root cracking and shares all other morphological characters.

\section{$5^{\text {th }}$ group}

IM-14 and IM-16 differ only in primary vine pigmentation, secondary vine pigmentation and root shape, also IM-15 is closely placed in this group as IM-14 and IM-15 shares the same secondary vine characters and IM-15 and IM-16 shares the same root shape morphology

$6^{\text {th }}$ group

IM-8 and IM-9 differ in their secondary vine character, immature leaf color, surface defects, root formation. IM-11 is closely placed to this group as it shares same vine color character with IM-8, same immature leaf color with IM-9 and same root formation and root cracking with IM-8.

IM-4 differ from others because of that the secondary vine pigmentation is entirely different from all others, but it shares same with IM-6. That is why it is placed near to IM-6.

IM-6differs from all other accessions in its secondary vine pigmentation, leaf lobe type and shape of central leaf lobe, these two characters are not expressed in any other accession that is why it is placed separately.
Table 4. Cluster distribution of 18 collection of Ipomoea mauritiana

\begin{tabular}{|c|c|c|}
\hline Cluster No. & Accessions in cluster & $\begin{array}{c}\text { Accessions included in } \\
\text { clusters }\end{array}$ \\
\hline I & IM-1 and IM-2 & - \\
\hline II & IM-12 and IM-18 & IM-17 \\
\hline III & IM-5 and IM-10 & IM-3 \\
\hline IV & IM-7 and IM-13 & - \\
\hline V & IM-14 and IM-16 & IM-15 \\
\hline VI & IM-8, IM-9 and IM-11 & IM-4 and IM-6 \\
\hline
\end{tabular}

IM-1 (Malappuram) and IM-2 (Malappuram), both collected from same district were placed in the same group as expected, but IM-6 collected from Nileswaram and IM-7 collected from Cheemeny, both from the same district exhibits large variations, and was grouped separately in the dendrogram. IM-5 and IM-9 collected from Kanjirapuzha, Palakkad were placed separately in the dendogram, also the same was with IM-8 and IM-12, both collected from Valliyakunnu, Malappuram. Thus indicating the distribution is independent of the geographical zones characterizing the accessions.

Quantitative characters also showed variability (Table 5). The leaf lobe number ranged from 3 to 7 and in $72.22 \%$ of the collection showed 5-lobed leaves and only IM- 6 with 3 lobes. The average leaf length varies from $2.77 \mathrm{~cm}$ in IM-13 to $5.70 \mathrm{~cm}$ in IM-10. The leaf breadth varies from $2.23 \mathrm{~cm}$ in IM-13 to $5.93 \mathrm{~cm}$ in IM-10 and the petiole length varies from 2.11 in IM-12 to 5.23 in IM-10.

IM-3 produced single tuber and maximum tubers were produced by IM-4 with an average of 4.66 numbers of roots. The root length was high in IM-9 and least in IM-16. The average root fresh weight per plant was found to be high in IM-10 (1194.10g), while the least was in IM-17 (77.80g). The same collections gave highest and lowest dry weight and were $190.03 \mathrm{~g}$ in IM-10 and $13.53 \mathrm{~g}$ in IM-17. The dry recovery percentage was high in IM-3 (21.23\%). Although the average root fresh and dry weight was higher in IM-10, it showed only a dry recovery percentage of $16.09 \%$ (Figure 3). 
Table 5. Selected quantitative characters of IM

\begin{tabular}{|c|c|c|c|c|c|c|c|}
\hline Collections & $\begin{array}{c}\text { Leaf lobe } \\
\text { number }\end{array}$ & $\begin{array}{c}\text { Leaf } \\
\text { length }(\mathrm{cm})\end{array}$ & $\begin{array}{c}\text { Leaf } \\
\text { breadth }(\mathrm{cm})\end{array}$ & $\begin{array}{c}\text { No of } \\
\text { roots }\end{array}$ & $\begin{array}{c}\text { Root length } \\
(\mathrm{cm})\end{array}$ & $\begin{array}{c}\text { Root fresh } \\
\text { weight }(\mathrm{g})\end{array}$ & $\begin{array}{c}\text { Root dry } \\
\text { weight }(\mathrm{g})\end{array}$ \\
\hline IM1 & 5 & 3.30 & 3.26 & 2.33 & 32.43 & 530.93 & 73.93 \\
\hline IM2 & 5 & 4.60 & 4.33 & 2.00 & 17.66 & 327.23 & 60.36 \\
\hline IM3 & 7 & 3.13 & 3.26 & 1.00 & 50.00 & 663.1 & 139.63 \\
\hline IM4 & 7 & 3.63 & 3.73 & 4.66 & 20.86 & 414.66 & 48.86 \\
\hline IM5 & 5 & 3.16 & 3.06 & 3.33 & 37.65 & 757.03 & 103.90 \\
\hline IM6 & 3 & 2.96 & 3.00 & 1.33 & 15.32 & 126.20 & 54.80 \\
\hline IM7 & 7 & 3.46 & 3.43 & 3.00 & 24.63 & 549.73 & 86.13 \\
\hline IM8 & 5 & 3.41 & 3.33 & 2.66 & 55.56 & 977.20 & 181.36 \\
\hline IM9 & 5 & 3.33 & 3.53 & 3.00 & 40.95 & 774.4 & 146.20 \\
\hline IM10 & 5 & 5.70 & 5.93 & 3.66 & 25.20 & 1194.10 & 190.03 \\
\hline IM11 & 5 & 3.23 & 3.03 & 1.33 & 26.33 & 441.70 & 76.23 \\
\hline IM12 & 5 & 3.00 & 3.01 & 2.66 & 35.38 & 437.53 & 71.06 \\
\hline IM13 & 5 & 2.77 & 2.23 & 3.00 & 22.20 & 792.20 & 137.10 \\
\hline IM14 & 5 & 2.93 & 2.70 & 1.33 & 26.05 & 203.96 & 16.76 \\
\hline IM15 & 5 & 3.43 & 3.14 & 3.00 & 30.94 & 534.60 & 100 \\
\hline IM16 & 5 & 3.10 & 2.73 & 2.00 & 15.66 & 269.0 & 44.83 \\
\hline IM17 & 5 & 3.46 & 3.00 & 1.66 & 19.30 & 77.80 & 13.53 \\
\hline IM18 & 7 & 3.63 & 3.26 & 4.33 & 22.30 & 575.11 & 110.10 \\
\hline
\end{tabular}

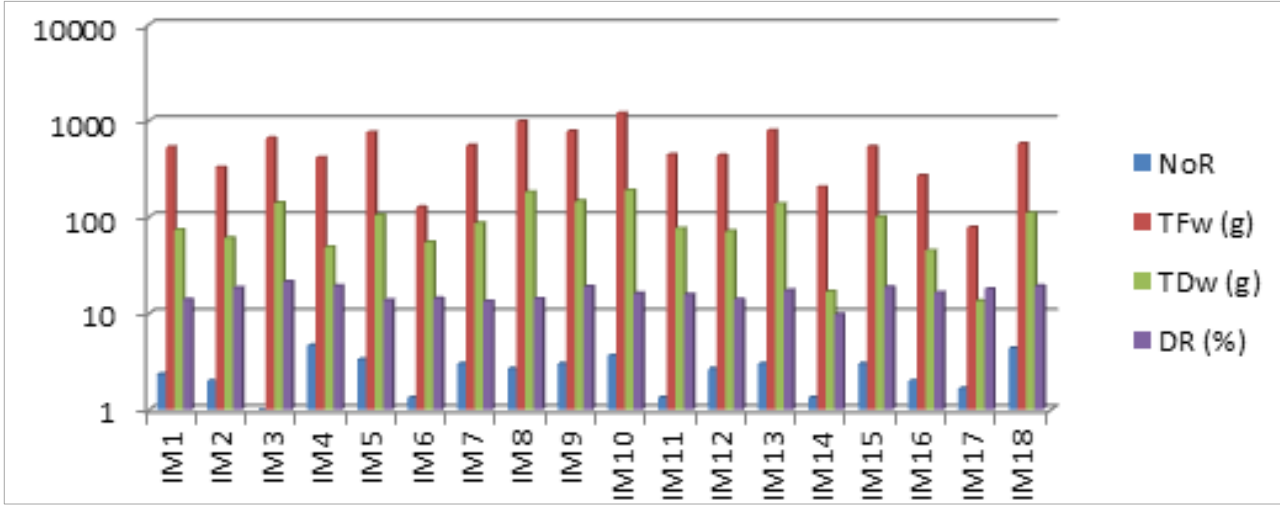

Figure 3. Storage root descriptors (Number of roots-NoR, Tuber fresh weight-TFw, Tuber dry weight-TDw, Dry recovery percentage-DR) evaluated in 18 collections of Ipomoea mauritiana

This is the first characterization report of I. mauritiana collections and the results will enhance crop improvement through expansion of knowledge of available genetic diversity. The most significant variation was observed in predominant and secondary vine colour, mature leaf colour, root surface defects, root cracking, number of leaves, leaf length and breadth, petiole length, root length, average root fresh and dry weight. Similar results were obtained by [4] on studying six varieties of Ipomoea batatas (L). The study showed significant variation in leaf, width, length, thickness, area, shape, arrangement, margin and venation and the colour index, revealed significant variations. Also the morphological characters of the roots were found to be different for the different cultivars.

It was observed from the study that some genotypes were collected from the similar geographical areas, doesn't exhibit similar morphological characters. The morphological studies done on 14 Evolvulus alsinoides Linn, a memory enhancing herb, from different regions of Maharashtra, $90 \%$ similarity was obtained irrespective of their collection locations [9].This suggests that morphological divergence observed cannot solely attributed to environmental variations, but possibly have genetic basics

In many situations, the most obtained assessment of genetic variation is that of measuring morphological or phenotypic variation. The sharing of phenotypic character is interpreted as an indication of relatedness [6]. Plants exhibits natural variation in form and structure. Within a single individual, parts are repeated, that may differ in form and structure from other similar plants [10].

Phenotypic differences are not necessarily correlated 
with the number of underlying gene mutations and differences in phenotypic characters are not necessarily reflections of different genetic events [1]. A combination of morphological and molecular analyses may be the most useful alternative when trying to understand all aspects of genetic variations within a species. Exploitation of phenotypic traits increases our knowledge of genetic variability available and strongly facilitates breeding programs [9]. The phenotypic characterization process saves storage space and makes selection by plant breeders simple. Selection of genotypes by phenotypic traits has contributed to the domestication of plants with desired traits that meet farmers' demands [5].

In order to draw conclusions, it is necessary to repeat the trials in a range of localities or alternatively by growing the plants in a controlled environment since morphological characteristics is known to be susceptible to environmental influences [2]. Five IM collections (IM5, IM8, IM9, IM10 and IM13) showed potential for further evaluation based on better root yield in terms of fresh and dry weight. Phenotypic analyses revealed wider range of variability among IM collections, while RAPD analyses showed narrow variability [7]. Further studies need to be conducted to confirm existence of genetic variations amongst the genotypes through ISSR/SSR analyses. Identification of germplasm collections for different agronomical characters in phenotypically divergent sources would help in future breeding programs.

\section{Acknowledgements}

The authors thank the Tata Trust, Mumbai for financial support for the project and Arya Vaidya Sala, Kottakkal for providing all the facilities required for the programme.

\section{REFERENCE}

[1] K. Bachmann, Nuclear DNA Markers in Angiosperm Taxonomy, ActaBotanica, Neerlandica, 41 (4), 369-384, 1992

[2] J. E. Berinyay, D.A. Fontem and R.R. Focho, Plant Genetic Resources Newsletter. 131, 42-48, 2002

[3] Z Huaman, Descriptors for sweet Potato Rome: International Board of Genetic Resources/ Asian Vegetable Research and Development Center, 133, 1991.

[4] S. M. Hue, S. Chandran and A.N Boyce. Variation of Leaf and Storage Root Morphology in Ipomoea batatas L. (Sweet potato) Cultivars. Acta Horticulture. 943, 73-80, 2012

[5] P. Gepts. Crop Domestication as a Long Selection Experiment. In: Jules, J. (ed.). Plant Breeding Reviews 24: 1-23. John Wiley \& Sons, California, 2004
[6] M. Jasienski, F. J.Ayala snd f. A. Bazza, Phenotypic Plasticity and Similarity of DNA among Genotypes of an Annual plant, Heredity. 78, 176-181, 1997

[7] N.M. Lakshmi, P. R Rahul, S. SadheeshnaKumari, P. S Geetha and Indira Balachandran, Proc. Extended Abstracts 29th Kerala Science Congress, January 28-30, Marthoma College, Thiruvalla, Kerala State Council for Science Technology and Environment, 2017.

[8] M.T. Manamela, Morphological Characterization and Cryopreservation of Sweet Potato, Ipomoea batatas (L) and Accessions at the NPGRC of South Africa. CBM Swedish Biodiversity Centre. 68, 3-45, 2009.

[9] V.B. Naikawadi, M.L. Abire, V. H. Lokhande, R.P. Ghorpade and T.D. Nikam, Morphological, Biochemical and Molecular Characterization of Evolvulus alsinoides Linn. A Memory Enhancing Herb, Indian Journal of Biotechnology, 15, 48-56. 2015

[10] H. Persson. Estimating Genetic variability in Horticultural Crop Species at Different Stages of Domestication. Doctoral Thesis. Swedish University of agricultural Sciences, 14

[11] N.K. Rao, Plant genetic resources: advancing conservation and use through biotechnology. African Journal of Biotechnology. 3(2), 136-145, 2004.

[12] B.M. Reed, F. Engelmann and M. E Dullo, Engels JMM (eds.), PGRI Handbooks for Genebanks No International Plant Genetic Resources Institute. Rome, Italy, 2004

[13] C.M. Rick and M. Holle, Andean Lycopersicumesculentumvar. cerasiformine. Genetic variation and its evolutionary significance. Ecol. Bot. 44, 69-78, 1990.

[14] N. Sasidharan and P. K. Muraleedharan, The Raw drugs Requirement of Ayurvedic Medicine Manufacturing Industry Kerala. KFRI Research Report No. 32, Kerala Reasearch Institue Peechi, Thrissur, 88, 2009.

[15] V.V. Sivarajan and I. Balachandran, Ayurvedic Drugs and Their Plant Sources. Oxford and India Book House Publishing Co. Pvt. Ltd., New Delhi, India. 473-474, 1994. 